\title{
Ichthyofauna of Seridó/Borborema: a semi-arid region of Brazil
}

\author{
Márcio Joaquim da Silva ${ }^{1,3}$, Telton Pedro Anselmo Ramos ${ }^{2}$, Virginia Dantas Diniz ${ }^{2}$, Robson Tamar da \\ Costa Ramos ${ }^{2}$ \& Elvio Sergio Figueredo Medeiros ${ }^{1}$ \\ ${ }^{1}$ Grupo de Ecologia de Rios do Semiárido, Universidade Estadual da Paraíba, Centro de Ciências Biológicas \\ e Sociais Aplicadas, and Rua Horácio Trajano de Oliveira, Cristo Redentor, CEP: 58020-540, João Pessoa, \\ PB, Brasil. www.uepb.edu.br \\ ${ }^{2}$ Laboratório de Sistemática e Morfologia de Peixes, Universidade Federal da Paraíba, Centro de Ciências \\ Exatas e da Natureza, Jardim Cidade Universitária, CEP: 58059-900, João Pessoa, PB, Brasil. \\ www.ufpb.br \\ ${ }^{3}$ Corresponding author: Márcio Joaquim da Silva, e-mail: silva.marcio.j@gmail.com
}

SILVA, M.J., RAMOS, T.P.A., DINIZ, V.D., RAMOS, R.T. da C, MEDEIROS, E.S.F. Ichthyofauna of Seridó/ Borborema: a semi-arid region of Brazil. Biota Neotropica. 14(3): e20130077. dx.doi.org/10.1590/1676-06032014 007713

\begin{abstract}
The Seridó/Borborema region is located between the States Paraíba and Rio Grande do Norte and a priority area for conservation of the Caatinga. This region is under the hydrological influence of the middle portion of Piranhas-Açu River basin. Previous systematic inventories of the ichthyofauna of this Caatinga's area are not significant. The Caatinga fish fauna is threatened due the advancement of historic anthropogenic activities, mainly agricultural. Furthermore, another relevant aspect is the recent governmental decision of transferring water from São Francisco River to other Northern river basins, which includes the Piranhas-Açu basin. This study performed a systematic survey of the Seridó/ Borborema's ichthyofauna. The sites were sampled during the years 2006 and 2007 (four annual, diurnal samples), using three different types of gear: beach seine nets, cast net and gillnets. We captured 13,009 individuals of 5 orders, 14 families, 28 genera and 35 species of fish. The predominant orders were Characiformes (21 species), Siluriformes (6) and Perciformes (5). The greatest number of species (11) was catch from the family Characidae, followed by Cichlidae (5) and Loricariidae (4). This inventory produced a comprehensive sampling of the middle portion of Piranhas-Açu River basin and its result overcomes the diversity reported in previous studies (22 species) on the same region.
\end{abstract}

Keywords: Inventory, Fish, Piranhas-Açu River, Caatinga, Northeastern Brazil.

SILVA, M.J., RAMOS, T.P.A., DINIZ, V.D., RAMOS, R.T. da C, MEDEIROS, E.S.F. Ictiofauna do Seridó/Borborema: uma região semiárida do Brasil. Biota Neotropica. 14(3): e20130077. dx.doi.org/10.1590/1676-06032014007713

Resumo: A região Seridó/Borborema, localizada entre os Estados da Paraíba e do Rio Grande do Norte, é uma área prioritária para conservação da Caatinga e encontra-se sob domínio hidrológico da porção média da bacia do rio Piranhas-Açu. Levantamentos sistemáticos sobre a ictiofauna desta região da Caatinga realizados até esse momento são pouco expressivos. A ictiofauna da Caatinga sofre ameaças devido ao avanço histórico de atividades antrópicas, principalmente agropastoris. Além disso, outro aspecto que merece destaque é a recente implantação da obra de integração do rio São Francisco com as bacias hidrográficas do Nordeste Setentrional. O presente estudo realizou um levantamento sistemático da ictiofauna da região Seridó/Borborema. As amostragens foram realizadas entre os anos de 2006 e 2007 (quatro amostragens anuais diurnas), utilizando redes de arrasto, tarrafa e redes de emalhar. Foram capturados 13.009 indivíduos pertencentes a 5 ordens, 14 famílias, 28 gêneros e 35 espécies de peixes. As ordens predominantes foram Characiformes (21 espécies), Siluriformes (6) e Perciformes (5). Characidae foi a família com o maior número de espécies (11), seguida por Cichlidae (5) e Loricariidae (4). Este inventário produziu uma abrangente amostragem da porção média do rio Piranhas-Açu e seu resultado supera a diversidade registrada em estudos prévios (22 espécies) da mesma região.

Palavras-chave: Inventário, Peixe, Rio Piranhas-Açu, Caatinga, Nordeste Brasileiro. 


\section{Introduction}

The knowledge related to the freshwater fishes of Brazil has increased during the last decades (Buckup et al. 2007, Menezes et al. 2007), as to the Neotropical region (Vari 1983, Reis et al. 2003, Kullander \& Ferreira 2006). However, studies are unevenly distributed in Brazil. While some areas of the country are relatively well documented, studies available from the ecoregion Midle Eastern Portion of Northeastern Brazil (Nordeste Médio-Oriental) are still not expressive, either due to the low extension of the inventory, or due to the lack of clarity about the taxonomic identity of its components (Santos \& Zanata 2006, Buckup et al. 2007, Langeani et al. 2009, Nogueira et al. 2010, Ramos 2012). The more comprehensive and cited general work on the diversity of Northeastern freshwater fish was carried out by Rosa et al. (2003), a study limited to the Caatinga region, that recorded 240 species. The authors cited above argue that the current scenario of knowledge about the fish fauna of Northeastern Brazil may only be changed with conducting extensive sampling programs in the various river basins of the region, and their results being analyzed from new systematic reviews. Therefore, estimates of diversity of freshwater fish in the Northeastern Brazil may be premature, considering the existence of the few representative collections from this region (Menezes 1996, Rosa et al. 2003, Ramos et al. 2005).

Subprojects as part of large projects like PROBIO (Project of the conservation and sustainable use of Brazilian biological diversity) and PPBio (Program of biodiversity research) are among recent programs aiming to increase knowledge of fish diversity of Brazilian Northeastern Region. Recently, Ramos (2012) conducted an inventory in the Parnaíba River basin in the States of Ceará, Piauí and Maranhão, and recorded 143 species of freshwater fish. Among those species 23 were new records for the basin, 25 are new species to science, and 50 are endemic species - almost $40 \%$ of 136 native species diagnosed by author.

The Caatinga extends along most of Northeastern region and is one of the most altered regions of Brazil, as well as its associated aquatic systems, mainly by human activities such as farming (Coimbra-Filho \& Câmara 1996, Leal et al. 2003). Another relevant aspect is the recent governmental decision of transferring water from São Francisco River to other Northern river basins, which includes the Piranhas-Açu. Certainly this action will bring major changes, thus, it is urgent to expand knowledge about the ichthyic diversity of the region. Tabarelli and Silva (2003) identified priority areas for conservation of the Caatinga, classified according to the degree of biological importance and urgency of conserving species as: Extreme, Very High, and High Priority. Among those areas, the Seridó/Borborema stands out as the only Extreme Priority area in the Piranhas-Açu River basin, and incorporates one of its main tributaries, the Seridó river. The Seridó/Borborema region is addressed in this study, which aimed to survey the fish species occurring there and is a byproduct of the PPBio, a program of taxonomic and ecological assessment of the Northeastern Brazilian region.

\section{Material and methods}

\section{Study area}

This study was performed in the Seridó/Borborema region which lies within the middle portion of Piranhas-Açu river basin (Figure 1). The relief of Seridó/Borborema region dates from Precambrian, formed by igneous and metamorphic rocks (Felipe \& Carvalho 1999). The characteristic climate of Brazilian Semi-arid is BSh, according to Köppen-Geiger's classification (Rubel \& Kottek 2010), with rainfall between 400$800 \mathrm{~mm}$ (historical average of years 1998-2007; CPTEC 2011), average annual temperature $30.7^{\circ} \mathrm{C}$, with minimum of $29.3^{\circ} \mathrm{C}$ (February) and maximum of $31.7^{\circ} \mathrm{C}$ (October) (Amorim et al. 2005). Leal et al. (2003) affirm that the climate of studied region is a result of high solar radiation, low nebulosity, high average annual temperature, low rates of relative humidity, high potential evapotranspiration, as well as low and irregular rainfall.

The vegetation of Seridó/Borborema region is the typical Caatinga's trees and low shrubs (Maia 2004). Species richness is low, with few rare or endangered species, showing associations of genera Mimosa, Caesalpinia and Aristida (Giulietti et al. 2003).

This study was conducted on five sampling sites during two years, one of them repeated in both years. The sites Cipo (CIP) and Recanto (REC) were sampled during 2006; Riacho da Serra (RSE) and Poço dos Patos (PPT), in 2007; Catureré (CAT) was assessed during the hydrological cycles of 2006 and 2007 (Figure 1). The 2006 samples were performed in March/ April, June, September and December; samples of 2007 were conducted in April, July, October and December.

\section{Collection and identification of specimens}

Four samples were performed at each sampling site (authorization $\mathrm{n}^{\circ}$ 032-DIFAP/IBAMA) using gillnets $(10 \mathrm{~m}$ long, mesh sizes 25, 35 and $45 \mathrm{~mm}$ ), manuals trawls (20 m long, $2.5 \mathrm{~m}$ height, mesh sizes $10 \mathrm{~mm}$; $4 \mathrm{~m}$ long, $2 \mathrm{~m}$ high, mesh sizes $5 \mathrm{~mm}$, and cast nets ( $2 \mathrm{~m}$ height, mesh sizes $12 \mathrm{~mm})$ with standardized effort (Medeiros et al. 2010). The fish were fixed in field with formalin $10 \%$ neutralized with sodium tetraborate.

The specimens were treated according to rules of scientific curation (Malabarba \& Reis 1987). Sorting and identification of specimens were carried out at Laboratory of Systematics and Morphology of Fishes of Universidade Federal da Paraíba, according to specific literature. Voucher specimens were deposited after identification in the Ichthyological Collection of the same institution (see appendix).

\section{Results and discussion}

Thirty-five species in 28 genera of 14 families distributed in five orders of teleostean fishes were recorded (Table 1). The order Characiformes was the most representative, with 21 species (Table 1). Among the families registered, Characidae (Characiformes) had the highest number of species (11), followed by Cichlidae (Perciformes), with five species, Loricariidae (Siluriformes), with four species, and Curimatidae (Characiformes), with three; from the remaining families were registered one or two species (Table 1). Other studies in the rivers, streams and artificial environments of Brazilian Semi-arid region revealed this same pattern of dominance (Medeiros \& Maltchik 2001, Ramos et al. 2005, Medeiros et al. 2006, Medeiros et al. 2008).

Among the registered species, four are introduced: Cichla ocellaris Bloch \& Schneider, 1801, Colossoma macropomum (Cuvier, 1818), Oreochromis niloticus (Linnaeus, 1758) and Poecilia reticulata Peters, 1860 (Table 1), corresponding to $11.4 \%$ of the recorded ichthyofauna. Except for Colossoma 


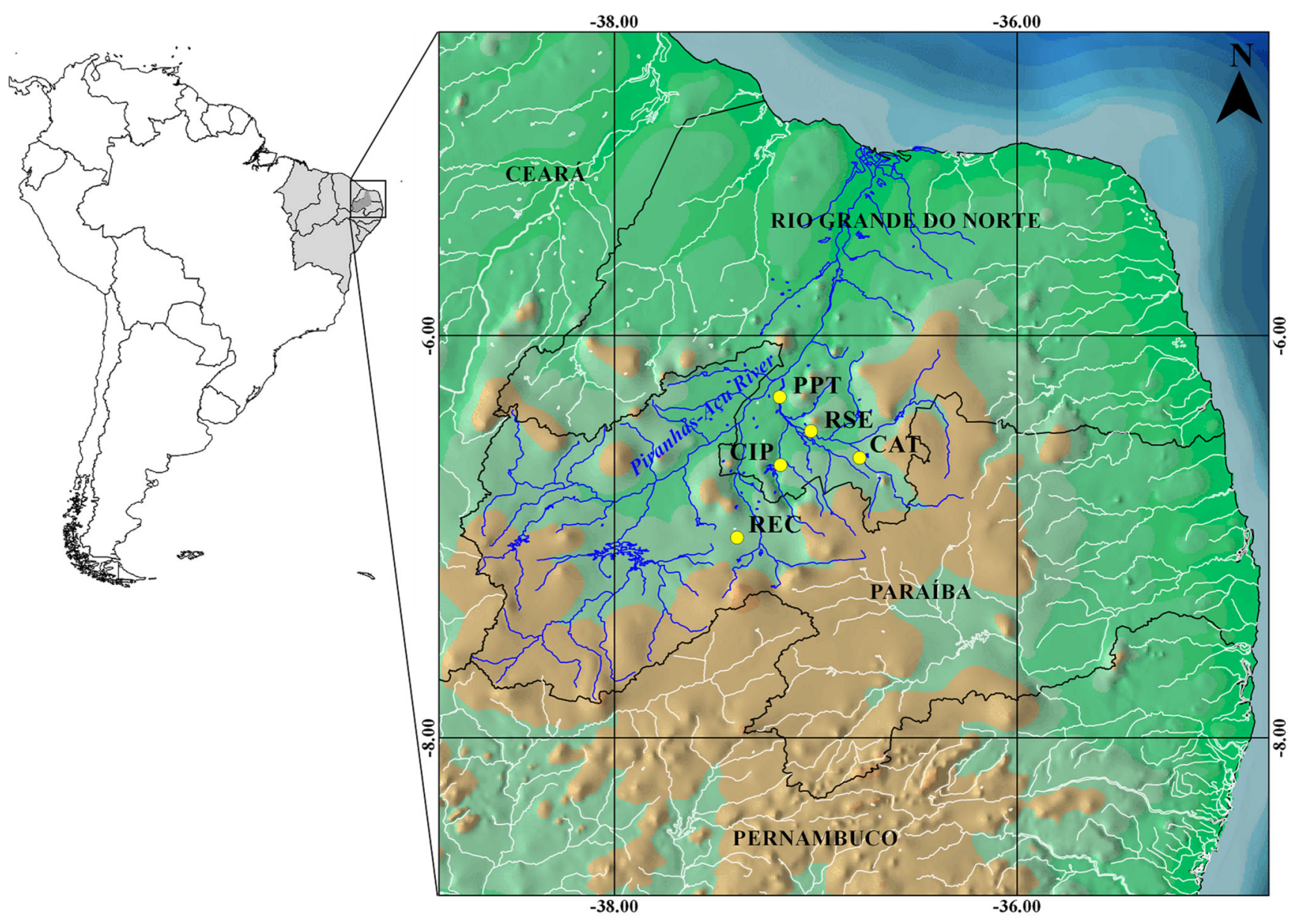

Figure 1. Study area showing major river systems and sampling sites in the semi-arid region of Brazil.

macropomum, which was registered only at the Recanto site, the three other aloctone species were sampled in three of the four study sites. There were no endangered species, when comparing the list of detected species with those contained in MMA (2008), IUCN (2012) and CITES (2013).

Astyanax aff. bimaculatus (Linnaeus, 1758), Astyanax. aff. fasciatus (Cuvier, 1819), Hoplias malabaricus (Bloch, 1794), Prochilodus brevis Steindachner, 1874 and Serrapinnus heterodon (Eigenmann, 1915) were the most widely distributed species in Seridó/Borborema region, being recorded in all sampling sites (Table 1). The four most abundant species in this inventory were Oreochromis niloticus (18.4\% of specimens), Astyanax aff. bimaculatus (17.4\%), Poecilia vivipara Schneider \& Bloch, 1801 (12.7\%), Hemigrammus marginatus Ellis, 1911 $(12.3 \%)$ and Serrapinnus heterodon (12.1\%) (Figure 2). Oreochromis niloticus (Tilapia) is an exotic species, as previously mentioned. The Tilapias are usually introduced from fish farming and have negatively impacted biodiversity at local level (GISP 2005, Attayde et al. 2007).

The collected specimens of Astyanax aff. bimaculatus, Hemigrammus marginatus and Serrapinnus heterodon accounted for $41.8 \%$ of all sampled individuals. These species belong to the group of "Piabas", of Characidae family. The reason for the high number of specimens of this group may be related to the habit of forming schools, which facilitates the capture of a larger number of individuals (Ramos 2012).
Other species with significant abundance was the "Guaru" Poecilia vivipara, a small fish able to survive in water with low oxygen content, and wide variation in salinity and temperature. This wide tolerance and its efficient reproductive strategy, allow the species to multiply rapidly and produce large numbers of individuals (Andreatta \& Mendonça 2001); the species also forms schools.

Astyanax aff. bimaculatus was among the most abundant species and was collected in all sampling sites. This is a generalist species (Mazzoni 2010, Silva et al. 2010) that can reproduce during all year through partitioned or total spawning, depending on the characteristics of the environment (Ihering \& Azevedo 1936, Geniari-Filho \& Braga 1996).

Among the carnivorous species registered [Serrasalmus rhombeus (Linnaeus, 1766), Hoplias malabaricus and Cichla ocellaris Bloch \& Schneider, 1801], Hoplias malabaricus was the most abundant and frequent (Figure 2). This result was expected and is in agreement with other studies in the region, which states Hoplias malabaricus as the top predator species commonly found in aquatic environments of Brazilian semiarid (Paiva 1974, Chaves et al. 2009).

This inventory produced a comprehensive sampling of the ichthyofauna occurring at the Seridó/Borborema region, on the middle portion of Piranhas-Açu River basin. The number of 35 species registered in this study, overcomes in more than $50 \%$ that stated by previous work in the same basin (Nascimento et 
Table 1. List of species collected in the Seridó/Borborema region. Taxonomic classification in accordance to Eschmeyer (2014); sampled sites: PPT $=$ Poço dos Patos, RSE $=$ Riacho da Serra, $\mathrm{CAT}=$ Catureré, $\mathrm{CIP}=$ Cipó and REC $=$ Recanto; $*$ Introduced species.

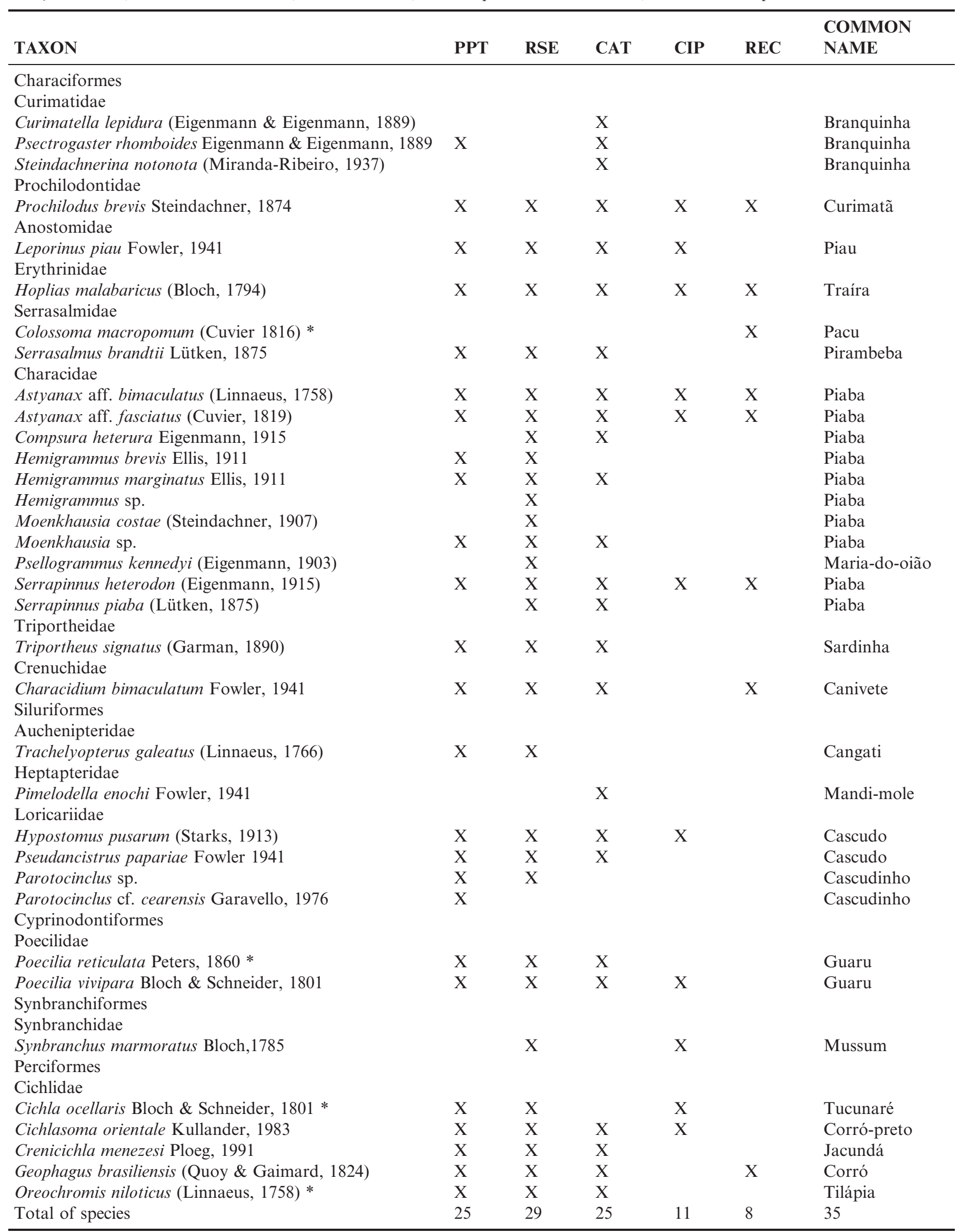


Ichthyofauna of Seridó/Borborema region, Brazil

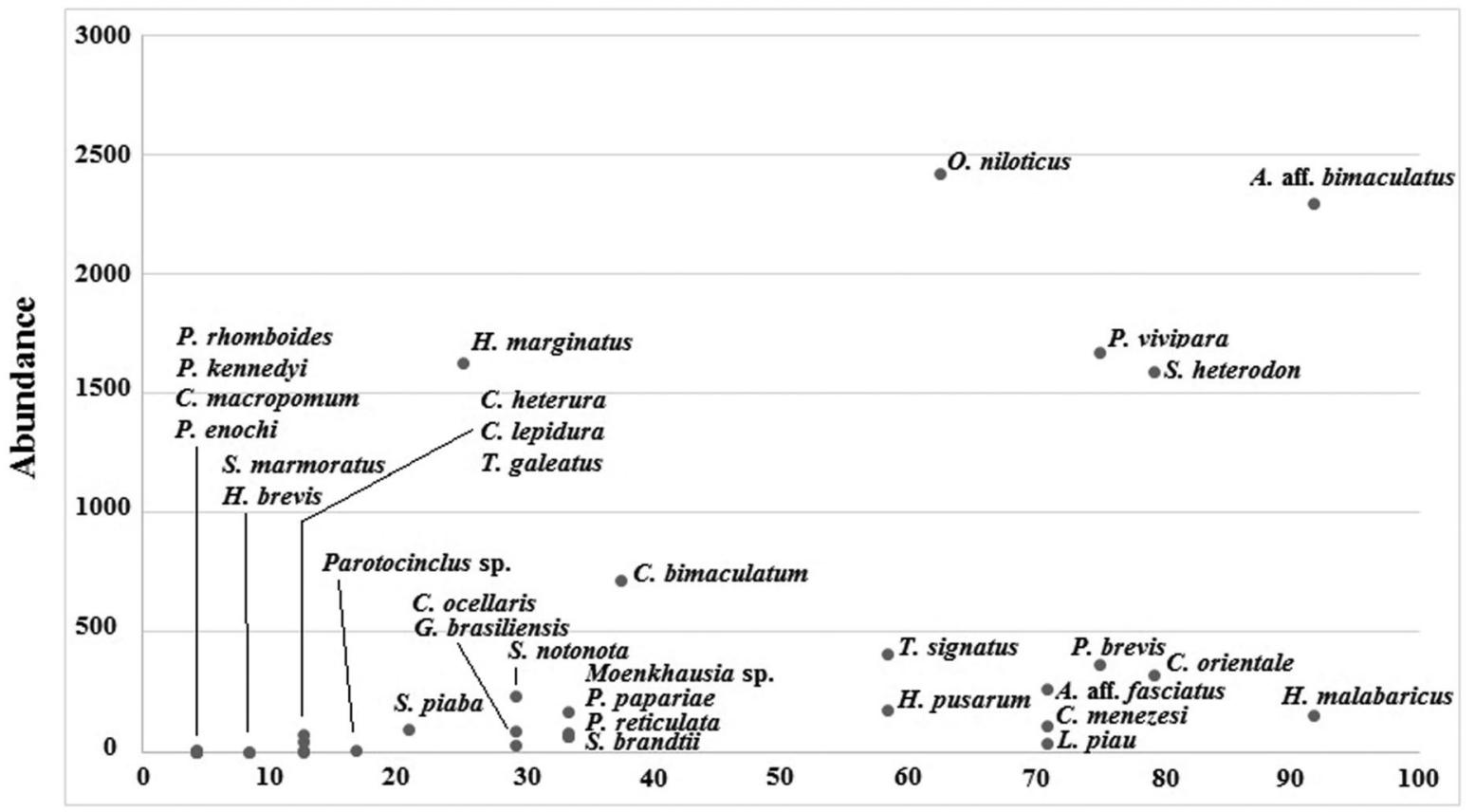

Frequency of occurrence (\%)

Figure 2. Most abundant fish species and their frequency of occurrence in the Seridó/Borborema region, Brazil.

al. 2011, 22 species) and others in the Curimataú River basin, adjacent to the study area (Ramos et al. 2005, Medeiros et al. 2006, 22 species). The results add data on the taxonomic composition and predominance of ichthyic elements in aquatic environments of Northeastern Brazil, in a priority area for the conservation of the Caatinga. Another relevant aspect is that this survey provides information on the ichthyofauna composition of Piranhas-Açu River basin before it receives water from the project of water transfer from São Francisco River to other Northern rivers basins.

\section{Appendix}

\section{Listing of vouchers}

UFPB6106, UFPB6107, UFPB6108, UFPB6109, UFPB6110, UFPB6111, UFPB6112, UFPB6113, UFPB6114, UFPB6121, UFPB6125, UFPB7878, UFPB7879, UFPB7880, UFPB7881, UFPB9684, UFPB9685, UFPB9686, UFPB9687, UFPB9688, UFPB9689, UFPB9690, UFPB9691, UFPB9692, UFPB9693, UFPB9694, UFPB9695, UFPB9696, UFPB9697, UFPB9698, UFPB9699, UFPB9700, UFPB9701, UFPB9702, UFPB9703, UFPB9704, UFPB9705, UFPB9706, UFPB9707, UFPB9708, UFPB9709, UFPB9710, UFPB9711, UFPB9712, UFPB9713.

\section{Acknowledgements}

The authors are grateful to Program for Research in Biodiversity (PPBio - Semi-Arid), to National Council of Technological and Scientific Development (MCT/CNPq 02/ 2006 - Universal 477545/2006-8), to Federal University of Paraíba (UFPB), to State University of Paraíba (UEPB) and to Foundation for Research Support of the State of Paraíba (Edital 02/2005 -FAPESQ/CNPq/UEPB - FAPESQ 68.0006/ 2006.0) by the logistical and financial support. MJS thanks the
UEPB for scholarship granting for scientific initiation (2006/ 2007 and 2007/2008) and ESFM thanks CNPq for the scholarship of Regional Scientific and Technological Development (CNPq 350082/2006-5).

\section{References}

Amorim, I.L., Sampaio E.V.S.B., \& Araújo, E.L. 2005. Flora e estrutura da vegetação arbustivo-arbórea de uma área de Caatinga do Seridó, RN, Brasil. Acta bot. bras. 19: 615-623, http:// dx.doi.org/10.1590/S0102-33062005000300023

Attayde, J.L., Okun, N., Brasil, J., Menezes, R. \& Mesquita, P. 2007. Impactos da introdução da tilápia do Nilo, Oreochromis niloticus, sobre a estrutura trófica dos ecossistemas aquáticos do Bioma Caatinga. Oecol. bras. 11 (3): 450-461, http://dx.doi.org/10.4257/ oeco.2007.1103.13

Buckup, P.A., Menezes, N.A. \& Ghazzi, M.S. 2007. Catálogo das Espécies de Peixes de Água Doce do Brasil. Rio de Janeiro: Museu Nacional.

Chaves, M.F., Torelli, J., Targino, C.H. \& Crispim, M.C. 2009. Dinâmica reprodutiva e estrutura populacional de Hoplias malabaricus (Bloch, 1794) (Characiformes, Erythrinidae) em açude da bacia do rio Taperoá, Paraíba. Biotemas 22(2): 85-89.

CITES. 2013. http://www.cites.org/eng/app/appendices.php (last accessed 12/11/2013).

Coimbra-Filho, A.F. \& Câmara, I.G. 1996. Os limites originais do bioma da Mata Atlântica na região Nordeste do Brasil. Rio de Janeiro: Fundação Brasileira para Conservação da Natureza.

CPTEC. 2011. www.cptec.inpe.br/proclima/ (last accessed 10/01/2012). Eschmeyer, W.N. 2014. Catalog of fishes: genera, species, references. http://research.calacademy.org/research/ichthyology/catalog/fishcatmain.asp (last accessed 30/04/2014).

Felipe, J.L.A. \& Carvalho, E.A. 1999. Atlas escolar do Rio Grande do Norte. João Pessoa: Grafset.

Geniari-Filho, O. \& Braga, F.M.S. 1996. Fecundidade e desova de Astyanax bimaculatus e $A$. schubarti (Characidae, Tetragonopterinae) na represa de Barra Bonita, Rio Piracicaba (SP). Rev. UNIMAR 16(2): 241-254. 
GISP. 2005. América do Sul invadida. A crescente ameaça das espécies exóticas invasoras. Secretaria do GISP. Giulietti, A.M., Du-Bocage-Neta, A.L., Paula, A.R.L., Barbosa, D.C., Nogueira, E., Sampaio, E.V.S.B., Silva, G.C., Machado, I.C., Vírginio, J.F., Maia, L.C., Griz, L.M.S., Queiroz, L.P., Lima, J.L.S., Silva, M.A., Figueiredo, M.A., Rodal, M.J.N., Barradas, M.M., Barbosa, M.R.V., Harley, R.M. \& Chaves, S.M. 2003. Vegetação: áreas e ações prioritárias para a conservação da Caatinga In Ecologia e Conservação da Caatinga (I.R. Leal, J.M.C. Silva \& M. Tabarelli, eds.). Recife: EDUFPE. p.112-131.

Ihering, R Von \& Azevedo, P. 1936. As piabas dos açudes nordestinos (Characidae, Tetragonopterinae). Arquivos do Instituto Biológico. 7: 75-110.

IUCN. 2011. www.iucnredlist.org (last accessed 23/08/2011.

Kullander, S.O. \& Ferreira, E.J.G. 2006. A review of the South American cichlid genus Cichla, with descriptions of nine new species (Teleostei: Cichlidae). Ichthyol. explor. freshw. 17: 289398 ,

Langeani, F.L., Buckup, P.A., Malabarba, L.R., Py-Daniel, L.H.R., Lucena, C.A., Rosa, R.S., Zuanon, J.A.S., Lucena, Z.M.S., Britto, M.R., Oyakawa, O.T. \& Gomes-Filho, G. 2009. Peixes de água doce In Estado da arte e perspectivas para a Zoologia no Brasil (R.M. Rocha \& W.A.P. Boeger, eds.). Curitiba: p.211-230.

Leal, I.R., Silva, J.M.C. \& Tabarelli, M. 2003. Ecologia e conservação da Caatinga: uma introdução ao desafio In Ecologia e Conservação da Caatinga (I.R. Leal, J.M.C. Silva \& M. Tabarelli, eds.). Recife: EDUFPE. p.13-16.

Maia, G.N. 2004. Caatinga: árvores e arbustos e suas utilidades. São Paulo: D\&Z

Malabarba, L.R. \& Reis, R.E. 1987. Manual de técnicas para a preparação de coleções zoológicas. Peixes. Campinas: Sociedade Brasileira de Zoologia.

Mazzoni, R. 2010. Alimentação e padrões ecomorfológicos das espécies de peixes de riacho do Alto Rio Tocantins, Goiás, Brasil. Iheringia 100(2): 162-168.

Medeiros, E.S.F. \& Maltchik, L. 2001. Fish assemblage stability in an intermittently flowing stream from the Brazilian semiarid region. Austral Ecology 26: 156-164.

Medeiros, E.S.F., Ramos, R.T.C., Ramos, T.P.A. \& Silva, M.J. 2006. Spatial variation in reservoir fish assemblages along semi-arid intermittent river, Curimataú River, northeastern Brazil. Campina Grande: Revista de biologia e ciências da terra. Suplemento Especial 1: 29-39.

Medeiros, E.S.F., Silva, M.J. \& Ramos, R.T.C. 2008. Application of catchment- and local-scale variables of aquatic habitat characterization and assessment in the Brazilian Semi-arid Region. Neotrop. biol. conserv. 3(1): 13-20.

Medeiros, E.S.F., Silva, M.J., Figueiredo, B.R.S., Ramos, T.P.A. \& Ramos, R.T.C. 2010. Effects of fishing technique on assessing species composition in aquatic systems in semi-arid Brazil. Braz. j. biol. 70: 255-262, http://dx.doi.org/10.1590/S151969842010000200004

Mendonça, J.P. \& Andreata, J.V. 2001. Aspectos reprodutivos de Poecilia vivipara (Bloch \& Schneider) (Poecilidae) da Lagoa Rodrigo de Freitas, Rio de Janeiro, Brasil. Rev. bras. zool. 18(4): 1041-1047, http://dx.doi.org/10.1590/S0101-81752001000400001
Menezes, N.A. 1996. Methods for assessing freshwater fish diversity. In: Biodiversity in Brazil: a first approach (C.E.M Bicudo \& N.A Menezes, eds.). CNPq, São Paulo. p.289-295.

Menezes, N.A., Weitzman, S.H., Oyakawa, O.T., Lima, F.C.T., Castro, R.M.C. \& Weitzman, M.J. 2007. Peixes de água doce da Mata Atlântica: lista preliminar das espécies e comentários sobre a conservação de peixes de água doce neotropicais. São Paulo, Museu de Zoologia, Universidade de São Paulo.

MMA. 2008. Livro vermelho da fauna brasileira ameaçada de extinção. 1.ed. - Brasília: MMA; Fundação Biodiversitas.

Nacimento, W.S., Araújo, A.S., Gurgel, L.L., Yamamoto, M.E., Chellappa, N.T., Rosa, R.S. \& Chellappa, S. 2011. Endemic fish communities and environmental variables of the Piranhas-Assu Hydrografic Basin in the Brazilian Caatinga Ecoregion. Animal Biology Journal 2(3): 97-112.

Nogueira, C., Buckup, P.A., Menezes, N.A., Oyakawa, O.T., Kasecker, T.P., Ramos-Neto, M.B. \& Silva, J.M.C. 2010. Restricted-range fishes and the conservation of Brazilian freshwaters. PLoS ONE, $5(6)$.

Paiva, M.P. 1974. Crescimento, alimentação e reprodução da traíra, Hoplias malabaricus (Bloch) no Nordeste brasileiro. Fortaleza: Imprensa universitária.

Ramos, T.P.A. 2012. Ictiofauna de Água Doce da Bacia do Rio Parnaíba. PhD Thesis, Federal University of Paraíba, João Pessoa.

Ramos, T.P.A., Ramos, R.T.C., Rosa, R.S., Groth, F. \& Beltrão, G.B.M. 2005. Diversidade de peixes (Ictiofauna) da bacia do rio Curimataú, Paraíba In Análise das variações da biodiversidade do bioma Caatinga: suporte a estratégias regionais de conservação. (F.S. Araújo, M.J.N. Rodal \& M.R.V. Barbosa, eds.). Brasília: Ministério do Meio Ambiente. p.291-317.

Reis, R.E., Kullander, S.O., Ferraris, J. \& Carl, J. 2003. Check List of the freshwater fishes of South and Central America. Porto Alegre: EDIPUCRS.

Rosa, R.S., Menezes, N.A., Britski, H.A., Costa, W.J.E.M. \& Groth, F. 2003. Diversidade, padrões de distribuição e conservação dos peixes da Caatinga In Ecologia e Conservação da Caatinga (I.R. Leal, J.M.C. Silva \& M. Tabarelli, eds.). Recife: EDUFPE. p.135-181.

Rubel, F. \& Kottek, M. 2010, Observed and projected climate shifts 1901-2100 depicted by world maps of the Köppen-Geiger climate classification. Meteorology. 19: 135-141, http://dx.doi.org/10.1127/ 0941-2948/2010/0430

Santos, A.C.A. \& Zanata, A.M. 2006. Fishes in the Brazilian Semi-arid In Towards Greater Knowledge of the Brazilian Semi-arid Biodiversity. (L.P. Queiroz, A. Rapini \& A.M. Giulietti, eds.). Brasília. p.97-102.

Silva, M.J., Figueiredo, B.R.S., Ramos, R.T.C. \& Medeiros, E.S.F. 2010. Food resources used by three species of fish in the semi-arid region of Brazil. Neotrop. ichthyol. 4: 825-833.

Vari, R.P. 1983. Phylogenetic relationships of the families Curimatidae, Prochilodontidae, Anostomidae and Chilodontidae (Pisces: Characiformes). Smithsonian Contributions to Zoology, Smithsonian Institution Press. n. 378.

Tabarelli, M. \& Silva, J.M.C. 2003. Áreas e ações prioritárias para a conservação da biodiversidade da Caatinga In Ecologia e Conservação da Caatinga. (I.R. Leal, J.M.C. Silva \& M. Tabarelli, eds.). Recife: EDUFPE. p.777-796. 